\section{Impact of Seasonal Ozone Exposure on Yield and Vegetative Growth of Primocane-fruiting Raspberry}

\author{
J.A. Sullivan, B.A. Hale, and D.P. Ormrod \\ Department of Horticultural Science, University of Guelph, Guelph, Ont. NlG \\ 2W1, Canada
}

Additional index words. air pollution, Rubus idaeus, stress, $\mathrm{O}_{3}$

\begin{abstract}
Factorial experiments in two growing seasons in open-top field chambers with two or three $\mathrm{O}_{3}$ concentrations and two primocane-fruiting raspberry (Rubus idaeus $\mathrm{L}$.) cultivars were used to obtain dose-response relationships describing the effects of seasonal $\mathrm{O}_{3}$ exposure on raspberry plant vegetative and reproductive growth. At the lower concentration $\left(0.12 \mu \mathrm{l} \cdot \mathrm{liter}^{-1}\right)$, the response to $\mathrm{O}_{3}$ was nonsignificant. However, at 0.24 $\mu l \cdot$ liter-1 $^{-1}$ ' 'Heritage' showed a significant decline relative to the control in cane height, node count, cane diameter, and dry weight. These changes were accompanied by a $52 \%$ decrease in yield, caused mainly by a reduction in fruit count. In contrast, vegetative and yield characters of the 'Redwing' were not affected by $\mathrm{O}_{3}$.
\end{abstract}

During July and August in southern Ontario, it is not unusual to have several $\mathrm{O}_{3}$ episodes, in which the ambient $\mathrm{O}_{3}$ concentration is $>0.08$ $\mu l \cdot$ liter $^{-1}$ for hours or sometimes days (Mukammal, 1984). These episodes, largely the result of transboundary movement of polluted air masses, have been measured over most of Ontario's agricultural regions. In the United States, $\mathrm{O}_{3}$ levels are typically higher and often approach $0.20 \mu \mathrm{l} \cdot$ liter $^{-1}$ (U.S. Environmental Protection Agency, 1992). It has been established that ambient $\mathrm{O}_{3}$ exposure causes growth reduction in many agronomic crops (Cooley and Manning, 1987; Heck et al., 1984). Considerably less information has been gathered on the response of fruit crops to $\mathrm{O}_{3}$, despite their relatively high value per hectare. The few completed studies have concentrated on cultivars adapted to California [e.g., strawberry (Takemoto et al., 1989)]. Small fruit have received little attention with the exception of grape, where photochemical air pollutants reduced yield by $\leq 13 \%$ (Thompson et al. 1969) and cultivar sensitivity differences were demonstrated (Musselman and Melious, 1984).

Ozone effects on primocane-fruiting raspberry growth and yield warrant attention due to the high dollar value per hectare and wide planting distribution of this species (Crandall and Daubeny, 1990). The recent introduction of early maturing, highly productive cultivars, such as 'Redwing' (Luby et al., 1987), has increased the potential economic return from this crop due to higher off-season prices, lack of competition from foreign markets, and relatively low management costs. Primocane-

Received for publication 21 Sept. 1993. Accepted for publication 6 May 1994. We gratefully acknowledge the finiancial assistance of the Ontario Ministry of Agriculture and Food and the technical assistance of Larry Pyear. The cost of publishing this paper was defrayed in part by the payment of page charges. Under postal regulations, this paper therefore must be hereby marked advertisement solely to indicate this fact. fruiting cultivars produce fruit on the upper primocanes (first year), and buds on the lower cane remain dormant until the second season (Jennings, 1988). Mowing canes in the early spring is a standard management practice in which only one crop is produced in the fall from the new flush of primocanes initiated on buds of the perennial root system. Therefore, the root system is perennial and the canes are managed as an annual crop. This combination of annual and perennial growth may increase the importance of various physiological characteristics associated with productivity maintenance, such as functional leaf area, photosynthesis, and shoot-to-root photoassimilate translocation.

In primocane-fruiting raspberry cultivars, functional leaf area is critical for fruit production in the current year. Current-year leaf area also provides the carbohydrates for the establishment of the reserves in roots and crowns that are used to initiate shoot growth the subsequent season (Crandall et al., 1974; Jennings and Carmichael, 1975). Runeckles and Chevone (1991) demonstrated that $\mathrm{O}_{3}$ reduces leaf area, photosynthesis, and root mass in a variety of species, and it may be critical to the primocane-fruiting raspberry vegetative and reproductive growth. Our objective was to examine the influence of seasonal $\mathrm{O}_{3}$ exposure on the yield and vegetative growth of two primocane-fruiting raspberry cultivars.

\section{Materials and Methods}

Plant culture. Cold-stored, tissue culture, 'Heritage' and 'Redwing' raspberry plants were transplanted to the greenhouse (Apr. and May 1988, respectively). Plants were placed in 16 -liter pots filled with a 1 peat : 2 pine bark mixture (w/w), watered daily, and fertilized twice weekly with a soluble fertilizer $20 \mathrm{~N}-$ 20P-20K (1.0 g.liter $\left.{ }^{-1}\right)$. After 8 weeks, all plants were moved outdoors until the initial week of $\mathrm{O}_{3}$ exposure. While outdoors, plants were watered daily and fertilized at the same rate as before using an automated system. During the preexposure phase outdoors, all plants were exposed to ambient $\mathrm{O}_{3}$ levels that are considered low and inconsequential in June and early July.

Ozone exposure and data collection. Plants were exposed to $\mathrm{O}_{3}$ once every 7 days, starting in the second week of July and continuing until the end of August, for a total of seven exposures. Ozone exposure occurred in open-top field chambers (Heagle et al., 1973), transparent cylinders $2.4 \mathrm{~m}$ high and $3.0 \mathrm{~m}$ in diameter with a double lower wall into which filtered air was forced and directed into the plant canopy through perforations in the inside lower wall. These chambers allowed good control of the gaseous atmosphere around plant canopies with a minimum of microclimatic modification. Between exposures, plants were maintained in nontreatment, open-top chambers that supplied filtered ambient air containing $\mathrm{O}_{3}$ at $0.04 \mu 1 \cdot$ liter $^{-1}$. Plants were exposed for 7 h (1000 to $1700 \mathrm{HR})$. During this period, the desired $\mathrm{O}_{3}$ concentration was a constant squarewave exposure. The actual $\mathrm{O}_{3}$ concentration in each chamber was recorded twice per hour during the exposure period.

In 1988, the plants were exposed to either activated-charcoal-filtered ambient air $\left(\mathrm{O}_{3}\right.$, $\leq 0.04 \mu \mathrm{l} \cdot$ liter $^{-1}$ ) or such air supplemented with $\mathrm{O}_{3}$ to $\approx 0.12 \mu \mathrm{l} \cdot$ liter $^{-1}( \pm 10 \%)$ in the chamber. There were four replications over time, each consisting of four plants (subsamples) per each treatment. Each replication was run on a different day of the week.

In 1989, a third treatment $\left(\mathrm{O}_{3}\right.$ at 0.24 $\mu 1 \cdot$ liter $^{-1} \pm 10 \%$ ) was added. A new set of plants was used for the 1989 study. These plants were managed in the same manner as those in the previous year. There were three replications over time, each consisting of four plants (subsamples) per each treatment. During both seasons, plants were watered daily and fertilized weekly with $20 \mathrm{~N}-20 \mathrm{P}-20 \mathrm{~K}(1.0$ g.liter $\left.{ }^{-1}\right)$. Perchloro-1,1'-bicyclopenta-2,4-diene (pentac; $0.6 \mathrm{~g} \cdot \mathrm{liter}^{-1}$ ) (Sandoz Agro Canada, Mississauga) was used initially for spider mite (Tetranychus urticae Koch) control; thereafter, predator mites (Phytoseiulus persimilis Athias Henriot) were used for pest control.

Following the seventh week of exposure in 1988 , the plants were moved to the greenhouse to allow fruit development before harvest. No supplemental heating or lighting was required during harvest. Ripe fruit were collected three times per week until destructive harvest (21 Sept. 1988) of shoots and roots 3 weeks after the final exposure. In 1989, plants remained in a chamber with filtered air until the harvest was completed. Harvests were terminated when berry size was $<2.0 \mathrm{~g}$. Canes were harvested and measured after dormancy in 1989.

Data analysis. An examination of the nonadjusted treatment means and standard deviations for 1988 indicated that these data were characterized by large and heterogenous (between treatments) standard deviations (e.g. 'Redwing' fruit yield and count and 'Heritage' cane and root fresh weights) and $\geq 3$ times the difference between cultivars. Consequently, paired $t$ tests were used to determine 
Cellular \& Whole-plant Physiology

differences between treatments within cultivars in 1988. Relative cultivar sensitivity was determined by comparing the type and magnitude of growth-yield attributes that were sensitive to $\mathrm{O}_{3}$. In 1989 , when we used three treatments, regression analysis was performed to determine significance.

\section{Results and Discussion}

Ozone at $0.12 \mu \mathrm{l} \cdot$ liter $^{-1}$ had no significant effect on vegetative or yield attributes of either 'Heritage' or 'Redwing'. The higher $\mathrm{O}_{3}$ concentration $\left(0.24 \mu \mathrm{l} \cdot\right.$ liter $\left.^{-1}\right)$ added in the second year of the study probably contributed to the detection of a cultivar $\times$ treatment interaction for some variables, indicating differential sensitivity between cultivars. 'Heritage' showed a linear decline in cane height, node count, and dry weight as $\mathrm{O}_{3}$ concentration increased. Cane diameter also declined, but the differences were not significant. However, 'Redwing' showed no significant decline in shoot or cane growth (Table 1). Larger diameter canes have been associated with higher yields in summerbearing raspberries (Lott, 1981). 'Heritage' cane dry weight declined $41 \%$ in response to $\mathrm{O}_{3}$ exposure because the canes were shorter with smaller diameter and fewer nodes. Privé et al. (1993) showed that node count in fallbearing raspberries is an important yield component and influences flowering time and leaf count. In primocane-fruiting raspberry, productive leaf area must be maintained during the summer because the upper third of the cane supplies carbohydrates to developing fruit (Privé et al., 1994). Productive leaf area is also important during the fall because spring vigor in perennial fruit crops depends on carbohydrates stored before dormancy.

Root growth responses to $\mathrm{O}_{3}$ were evaluated only in the first year of the study (data not reported). There was no significant difference in root dry weight between plants exposed to $\mathrm{O}_{3}$ and plants grown in charcoal-filtered air for either cultivar. These results contradict Lechowicz's (1987) observation that roots are frequently the most sensitive plant part of many species, although they are not directly exposed to $\mathrm{O}_{3}$. Fernandez and Pritts (1994) have demonstrated that raspberry roots are strong sinks in the plant, and they compete with aboveground sinks for carbohydrates. In our study, root growth was not affected by low $\mathrm{O}_{3}$ levels $\left(0.12 \mu \mathrm{l} \cdot \mathrm{liter}^{-1}\right)$ in 1988 , but in 1989 , $\mathrm{O}_{3}$ significantly reduced three out of four 'Heritage' cane characteristics. The nature of sourcesink relations in the raspberry and our data suggest that the raspberry responds differently to $\mathrm{O}_{3}$ than the typical pattern exhibited by many species (Lechowicz, 1987).

Yield and yield component responses to $\mathrm{O}_{3}$ were evaluated in both years of this study. In 1988, there was no significant response of fruit yield to seasonal $\mathrm{O}_{3}$ exposure at $0.12 \mu \mathrm{l} \cdot$ liter $^{-1}$, although 'Heritage' and 'Redwing' yields declined $36 \%$ and $41 \%$, respectively. In 1989 , the yield components of the two cultivars demonstrated different reactions to $\mathrm{O}_{3}$ exposure (Table 2). Total and marketable yield of 'Heritage' declined $52 \%$ and $47 \%$, respec-

Table 1. Effect of ozone on cane growth of two primocane-fruiting red raspberry cultivars in 1989.

\begin{tabular}{|c|c|c|c|c|c|}
\hline \multirow[b]{2}{*}{ Cultivar } & \multirow{2}{*}{$\begin{array}{c}\text { Ozone } \\
\text { level } \\
\left(\mu \mathrm{l} \cdot \text { liter }^{-1}\right)\end{array}$} & \multicolumn{4}{|c|}{ Cane } \\
\hline & & $\begin{array}{l}\mathrm{Ht} \\
(\mathrm{m})\end{array}$ & $\begin{array}{c}\text { Diam } \\
(\mathrm{cm})\end{array}$ & $\begin{array}{l}\text { No. } \\
\text { node }\end{array}$ & $\begin{array}{c}\text { Dry wt } \\
(\mathrm{g})\end{array}$ \\
\hline \multirow[t]{3}{*}{ Heritage } & 0 & 0.87 & 0.69 & 27 & 41.5 \\
\hline & 0.12 & 0.79 & 0.67 & 25 & 29.6 \\
\hline & 0.24 & 0.77 & 0.63 & 23 & 24.6 \\
\hline \multicolumn{6}{|c|}{ Significance } \\
\hline Linear & & $* *$ & NS & $*$ & * \\
\hline \multirow[t]{3}{*}{ Redwing } & 0 & 1.05 & 0.80 & 31 & 43.7 \\
\hline & 0.12 & 1.01 & 0.76 & 31 & 46.1 \\
\hline & 0.24 & 0.97 & 0.79 & 30 & 40.9 \\
\hline \multicolumn{6}{|c|}{ Significance } \\
\hline Linear & & NS & NS & NS & NS \\
\hline
\end{tabular}

${ }_{\mathrm{Ns}, *, * *}$ Nonsignificant or significant at $P \leq 0.05$ or 0.01 , respectively.

Table 2. Effect of ozone on yield and yield components of two primocane-fruiting red raspberry cultivars.

\begin{tabular}{|c|c|c|c|c|c|c|c|}
\hline \multirow[b]{2}{*}{ Cultivar } & \multirow{2}{*}{$\begin{array}{c}\text { Ozone } \\
\text { level } \\
\left(\mu \mathrm{l} \cdot \text { liter }^{-1}\right)\end{array}$} & \multicolumn{3}{|c|}{ Total } & \multicolumn{3}{|c|}{ Marketable } \\
\hline & & $\begin{array}{c}\text { Yield } \\
(\mathrm{g})\end{array}$ & $\begin{array}{c}\text { No. } \\
\text { berries }\end{array}$ & $\begin{array}{l}\overline{W t} \\
(\mathrm{~g})\end{array}$ & $\begin{array}{c}\text { Yield } \\
\text { (g) }\end{array}$ & $\begin{array}{c}\text { No. } \\
\text { berries }\end{array}$ & $\begin{array}{l}\mathrm{Wt} \\
(\mathrm{g})\end{array}$ \\
\hline \multirow{3}{*}{ Heritage } & 0 & 59.4 & 51 & 1.1 & 53.4 & 43 & 1.2 \\
\hline & 0.12 & 47.3 & 37 & 1.3 & 44.8 & 34 & 1.4 \\
\hline & 0.24 & 28.4 & 22 & 1.2 & 28.2 & 21 & 1.3 \\
\hline \multicolumn{8}{|c|}{ Significance } \\
\hline Linear & & $* *$ & $* *$ & NS & * & NS & NS \\
\hline \multirow[t]{3}{*}{ Redwing } & 0 & 67.6 & 66 & 1.0 & 64.0 & 58 & 1.1 \\
\hline & 0.12 & 79.5 & 66 & 1.2 & 75.2 & 60 & 1.3 \\
\hline & 0.24 & 105.1 & 85 & 1.2 & 100.1 & 76 & 1.3 \\
\hline \multicolumn{8}{|c|}{ Significance } \\
\hline Linear & & NS & NS & NS & NS & NS & NS \\
\hline
\end{tabular}

ws, *,**Nonsignificant or significant at $P \leq 0.05$ or 0.01 , respectively.

tively, in response to $\mathrm{O}_{3}$ at $0.24 \mu 1 \cdot$ liter $^{-1}$. The decreases in yield in the second year of the study were attributable to decreases in berry count rather than individual berry weight, which suggests a reduction in yield potential due to fewer flowers; however, flowers were not counted. Smaller 'Heritage' canes may have had fewer fruiting laterals or fewer flowers per lateral. Decreases in both of these yield components have been associated with decreases in general vigor (i.e., lower cane dry weight) (Dale and Topham, 1980) and fewer nodes per cane. The differential sensitivity of 'Heritage' compared to that of 'Redwing' may be related to maturity; 'Heritage' often matures 8 to 14 days later than 'Redwing' in southern Ontario (Privé et al., 1993). Exposure time relative to development stage may be critical to $\mathrm{O}_{3}$ sensitivity.

Decreases in vigor can have negative implications for the current and following season's production. Nonstructural carbohydrates peak in October for summer-bearing types and reach their lowest levels to support development of laterals at budbreak in early summer (Jennings and Carmichael, 1975). Primocane-fruiting raspberries are usually mowed in early spring to produce only a fall crop, placing all the demand for spring regrowth and vigor on carbohydrate reserves in the root and crown of the plant. Any reduction in carbohydrate reserves may leave plants with poor spring vigor that ultimately reduces yield. During growing seasons when other environmental conditions for vigorous development are suboptimal, damage from $\mathrm{O}_{3}$ injury may be compounded, leading to a greater decline in the planting's vigor and longevity.

\section{Literature Cited}

Cooley, D.R. and W.J. Manning. 1987. The impact of ozone on assimilate partitioning in plants: A review. Environ. Pollution 47:95-113.

Crandall, P.C., J.D. Chamberlain, and K.A. Biderbost. 1974. Cane characteristics associated with berry number of red raspberry. $\mathrm{J}$. Amer. Soc. Hort. Sci. 99:370-372.

Crandall, P.C. and H.A. Daubeny. 1989. Raspberry management, p. 157-213. In: G.J. Galletta and D.G. Himelrick (eds.). Small fruit crop management. Prentice Hall, Englewood Cliffs, N.J.

Dale, A. and P.B. Topham. 1980. Fruiting structure of the red raspberry: Multivariate analysis of lateral characteristics. J. Hort. Sci. 55:397-408.

Fernandez, G.E. and M.P. Pritts. 1994. Growth, carbon acquisition and source-sink relationships in 'Titan' red raspberry. J. Amer. Soc. Hort. Sci. (In press.)

Heagle, A.S., D.E. Body, and W.W. Heck. 1973. An open-top field chamber to assess the impact of air pollution on plants. J. Environ. Qualilty 2:365368.

Heck, W.W., W.W. Cure, J.O. Rawlings, L.J. Zaragoza, A.S. Heagle, H.E. Heggestad, R.J. Kohut, L.W. Kress, and P.J. Temple. 1984. Assessing impacts of ozone on agricultural crops: II. Crop yield functions and alternative exposure statistics. J. Air Pollution Control Assn. 34:810817.

Jennings, D.L. 1988. Raspberries and blackberries: Their breeding, disease and growth. Academic. San Diego.

Jennings, D.L. and E. Carmichael. 1975. Some physiological changes occurring in overwintering raspberry plants in Scotland. Hort. Res. 14:103-108.

Lechowicz, M.J. 1987. Resource allocation by plants under air pollution stress: Implications for plantpest-pathogen interactions. Botanical Rev. 53:281-300. 
Lott, R.V. 1981. Raspberry investigation: A preliminary study of the fruiting habit of the red raspberry—Rubus strigosus. Colorado Agr. Expt. Sta. Bul. 367.

Luby, J.J.,E.E. Hoover, D.S. Bedford, S.T. Munson, W.H. Gray, D.K. Wildung, and C. Stushnoff. 1987. 'Redwing' raspberry. HortScience 22:681682.

Mukammal, E. 1984. Report on oxidant climatology of Ontario. Canadian Climate Centre, Application and Impact Division, Environment Canada, Doensview, Ont. p. 70.

Musselman, R.C. and R.E. Melious. 1984. Sensitiv- ity of grape cultivars to ambient ozone. HortScience 19:657-659.

Privé, J.P., J.A. Sullivan, and J.T.A. Proctor. 1994. Carbon partitioning and translocation in primocane-fruiting red raspberries (Rubus idaeus L.) J. Amer. Soc. Hort. Sci. 119:604-609.

Privé, J.P., J.A. Sullivan, J.T.A. Proctor, and O.B. Allen. 1993. Climate influences vegetative and reproductive components of primocane-fruiting red raspberry cultivars. J. Amer. Soc. Hort. Sci. 118:393-399.

Runeckles, V.C. and B.I. Chevone. 1991. Crop response to ozone, p. 189-270. In: A.S. Lefohn (ed.). Surface level ozone exposures and their effects on vegetation. Lewis Publishers, Chelsea, Mich

Takemoto, B.K., A. Bytnerowicz, and D.M. Olszyk. 1989. Physiological responses of field-grown strawberry (Fragaria xananassa Duch.) exposed to acidic fog and ambient ozone. Environ. Expt. Bot. 29:379-386.

Thompson, C.R., E. Hensel, and G. Kats. 1969. Effects of photochemical air pollutants on Zimfandel grapes. HortScience 4:222-224.

U.S. Environmental Protection Agency. 1992. National air quality and emissions trends report, 1991. U.S. Environ. Protection Agency Rpt. 450-R-92-001. Research Triangle Park, N.C. 